\title{
POTENTIALS OF ENDOPHYTES OF Andrographis paniculata FOR THE PRODUCTION OF PLANT GROWTH PROMOTERS, ENZYMES AND ANTIMICROBIAL COMPOUNDS
}

\author{
M. Adhikari and M. Mukhopadhyay* \\ Department of Microbiology, Lady Brabourne College, Kolkata West Bengal, India
}

\begin{abstract}
In the present study, 9 bacterial and 6 fungal endophytes were isolated from surface sterilized leaf, stem and root samples of the medicinal plant - Andrographis paniculata (Kalmegh). The endophytes were screened for plant growth promoting traits (IAA, phosphate solubilization and $\mathrm{N}_{2}$ fixation), enzymes (cellulase and amylase) and antimicrobial compounds against 3 potent human pathogens- E. coli, Staphylococcus $s p$. and Vibrio $s p$. The majority of the isolated endophytes produced the phytohormone - IAA (ranging 2-45 $\mathrm{g} / \mathrm{ml}$ ), and 1 endophyte solubilized phosphate and fixed $\mathrm{N}_{2}$. All the fungal endophytes possessed cellulase and amylase activity. In the preliminary screening, 4 bacterial and 4 fungal endophytic isolates extract showed antagonistic activity against the 3 potent human pathogens which are known causative agents of urinary tract, skin and gastrointestinal tract infections, respectively. The endophytes of $A$. paniculata exhibiting broad and specific antimicrobial activity make them ideal candidates in medical purposes.
\end{abstract}

Keywords: Andrographis paniculata, Endophytes, Medicinal plant, PGP, Phytohormones

\section{INTRODUCTION}

After their discovery by Darnel Germany in 1904 (Freeman, 1904), the endophytes has revolutionized the field of plant microbe interaction. Endophytes are ubiquitous species of bacteria, fungi and actinomycetes (Chanway et al., 1996) that originates in the rhizospheric region and after gaining entry into the root interior by different mechanisms like cell wall hydrolysis, water flow, via wounds and tumour (Hallman, 1997; Siciliano et al., 1998), establish a mutualistic and symbiotic association with the host plant (Quispel et al., 1992). The endophytes are host specific (Dastogeer et al., 2018) and colonize different plant parts such as root, stem, leaves, apical bud etc. (Ulrich et al., 2008) without doing any substantial harm to their host (Kado et al.,

\footnotetext{
* Corresponding Author: moumahuya1@yahoo.com
} 
1992), but provide their host with a ton of benefits in the form of plant nutrients (Chen et al., 1995), phytohormones (Shi et al., 2009), enzymes (Uzma et al., 2016) pest and pathogen resistance and stress tolerance (Yaish et al., 2015) etc.

The endophytes aid in various plant growth promoting (PGP) abilities to the host plant in form of phytohormones such as indole 3 acetic acid, gibberellins, cytokinins (Ali et al., 2017); mineral nutrient assimilation such as $\mathrm{N}_{2}$ fixation and phosphate solubilization etc. Apart from the plant synthesized phytohormones, the endophyte produce phytohormones like indole 3 acetic acid (IAA) in a L-tryptophan dependent pathway which imparts additive growth promoting abilities to the host (Bal et al., 2013), by enhancing cell elongation, cell division and promoting tissue differentiation etc (Taghavi et al., 2009). Atmospheric nitrogen $\left(\mathrm{N}_{2}\right)$, is a limiting nutrient element to plant due to their inability to fix it, hence, the plants have to rely upon the rhizospheric microorganisms and chemical fertilizers for $\mathrm{N}_{2}$ supply. Recently, the endophytes are emerging as beneficial alternative source of $\mathrm{N}_{2}$ (Muangthong et al., 2015), because the plant interior with low partial $\mathrm{O}_{2}$ pressure and sufficient $\mathrm{N}_{2}$ accessibility, serve as a homely niche for $\mathrm{N}_{2}$ fixation (James and Olivares, 1998). The endophyte fixed $\mathrm{N}_{2}$ is required for plant growth and development without any persistent environmental hazards in the form of underground water contamination and greenhouse gas emission, as evident in chemical fertilizers. Phosphorus $(\mathrm{P})$ is an essential primary nutrient element in the form of ATP, sugar and nucleotides in plants (Saber et al., 2005) as well as for secondary metabolic processes like terpenoid biosynthesis, isopentenyl pyrophosphate, precursor of andrographolide (Vickery and Vickery, 1986; Dubay et al., 2003), bioactive compounds of medicinal plant Salvia miltiorrhiza (Lu et al., 2013), and Lens culinaris (Sarker and Karmoker, 2011). The application of chemical $\mathrm{P}$ fertilizers although increased the essential oil content of Mentha piperita (Sulandjari et al., 2007) and sunflower (Bahl et al., 2000), but they contain maximum amount of soluble inorganic phosphate, which gets immobilized and unavailable to the plants. Alternatively, rhizobacteria were also used for phosphate mobilization and increased upland crop yields (Goldstein et al., 1986). But nowadays, P solubilization by endophytes is well documented in crop plants like wheat (Jha and Kumar, 2009) and rice (He and Zhu, 1998) via release of protons, chelating agents and organic acids (Hussain et al., 2013) which helps in plant growth and development, pathogen resistance efficiently.

Apart from various primary and secondary metabolites, antioxidants, anticancer agents (Gunatilaka et al., 2006), the endophytic fungi also serves as potential sources of industrially relevant enzymes with valuable roles in biotechnology. They produce hydrolases like pectinase, lipase, proteinase, amylase, laccase, xylanase etc. extracellularly to resist pathogen invasion and nutrient acquisition from the host (Sunitha et al., 2013) which are available to the mankind with industrial and biomedical potentialities (Strobbel et al., 2003). 
In a study by Farnsworth et al. (1990), it is observed that an estimation of WHO has clearly reported that approx. $80 \%$ population of the developing countries use traditional medicinal plants for primary health care needs, which is also getting in demand in developed countries due to their non-toxicity, abundance and affordable costs. Microorganisms have had promising use since decades as disease control agents. Recently endophytes of medicinal plants are also gaining importance in medical applications such as antibiotics, antivirals, antidiabetic and anticancer agent etc. production (Guo et al., 2010). The endophytes of medicinal plants, G.mangostana of Indonesia (Radji et al., 2014), Catharanthus roseus (Mukhopadhyay and Adhikari, 2020) etc. are shown to have diverse antimicrobial activity and resisted the growth of potential human pathogens.

Andrographis paniculata (commonly known as Kalmegh) is extensively used in India, China and South East Asia as a household medicine. Studies have reported that this herb has promising results in the treatment of fatal diseases like meningitis, acute hepatitis, influenza, malaria etc (Rao et al., 2014) and is widely used in the prevention of gastrointestinal, respiratory and urinary tract infections ( $\mathrm{Xu}$ et al., 2006; Zhang et al., 2009). However, very little studies have focused on the abilities of the endophytes of Andrographis paniculata to resist against pathogenic infections (Arunachalam et al., 2010; Gusmaini et al., 2013).

Our current study focuses on the isolation of endophytes from medicinal plant Andrographis paniculata and exploring their potential for plant growth promoters, extracellular enzymes and antimicrobial compounds.

\section{MATERIALS AND METHODS}

\section{Collection of plant materials}

Intact healthy Andrographis paniculata plant samples were collected from the local area and taken aseptically to the laboratory.

\section{Surface Sterilization and Isolation of endophytes}

From the plant samples, 1g each of stem, root and leaf was taken and thoroughly washed in running tap water and Tween 20 solution by vigorous shaking. This was followed by washing with sterile distilled water, and finally dipped in $70 \%$ ethanol for 3-5 minutes. Further, the roots were treated with $1 \%$ sodium hypochlorite solution for 2 minutes and rinsed 2-3 times with sterile Milli-Q water following (Sucuia and Cornea, 2019). The sterilized samples were then ground to prepare slurry and various dilutions were prepared with $0.85 \%$ sterile saline water. From the prepared dilutions, $0.1 \mathrm{ml}$ was dispensed on Nutrient agar and Czapek Dox agar plates and incubated at $37{ }^{\circ} \mathrm{C}$ for $24 \mathrm{~h}$. After the incubation period, the endophyte colonies were selectively isolated and further examined by staining and microscopic analysis. 


\section{Screening of bacterial isolates for PGP trait analysis}

\section{IAA production}

The bacterial isolates were aseptically inoculated into $20 \mathrm{ml}$ of IAA media $\left(\mathrm{NaNO}_{3}\right.$ $0.2 \%, \mathrm{~K}_{2} \mathrm{HPO}_{4} 0.1 \%, \mathrm{Na}_{2} \mathrm{HPO}_{4} 0.2 \%, \mathrm{MgSO}_{4} 0.01 \%, \mathrm{CaCO}_{3} 0.2 \%$, Glucose $1 \%$ ) supplemented with $0.5 \%(\mathrm{v} / \mathrm{v})$ of L- tryptophan and incubated for 10 days at $28^{\circ} \mathrm{C}$. After 10 days, the isolates were centrifuged at $3000 \mathrm{rpm}$ for $20 \mathrm{~min}$ and the supernatant was analyzed for IAA production following Gordon and Weber, 1951 by using freshly prepared Salkowski reagent and assessed for the development of red colour as positive result. Standard graph was plotted from known concentration of IAA and the amounts of IAA produced by the isolates were measured at $530 \mathrm{~nm}$ by spectrophotometeric analysis.

\section{Phosphate Solubilization}

The endophytic bacterial isolates were screened for phosphate solubilization by inoculating into Pikovskaya medium (containing dextrose $10 \mathrm{gm}$, Tricalcium phosphate $5 \mathrm{gm},\left(\mathrm{NH}_{4}\right)_{2} \mathrm{SO}_{4} 0.5 \mathrm{gm}, \mathrm{NaCl} 0.2 \mathrm{gm}, \mathrm{MgSO}_{4} 0.1 \mathrm{gm}, \mathrm{KCl} 0.2 \mathrm{gm}, \mathrm{FeSO}_{4}$ $0.002 \mathrm{gm}$, Yeast Extract $0.5 \mathrm{gm}, \mathrm{MnSO}_{4} 0.002 \mathrm{gm}$, Agar-20 gm, distilled water 1liter) and incubated at $30^{\circ} \mathrm{C}$ for 7 days (Pikovskaya, 1948). Finally, the media plates were observed for the formation of clear halo around the colony due to the utilization of tricalcium phosphate present in the medium.

\section{Nitrogen Fixation}

The bacterial isolates were inoculated into slants of Glucose $\mathrm{N}_{2}$ free mineral media (containing glucose-10 gm, $\mathrm{K}_{2} \mathrm{HPO}_{4} 1 \mathrm{gm}, \mathrm{MgSO}_{4} 0.20 \mathrm{gm}, \mathrm{CaCO}_{3} 1 \mathrm{gm}, \mathrm{NaCl} 0.2$ gm, $\mathrm{FeSO}_{4} 0.10 \mathrm{gm}, \mathrm{Na}_{2} \mathrm{MO}_{4}-0.005 \mathrm{gm}$, Agar-10 gm, distilled water 1 liter) containing bromothymol blue solution and incubated at $30^{\circ} \mathrm{C}$ for 7 days and were observed for the appearance of prussian blue colour as indicative of nitrogen fixation by the isolates.

\section{Screening of fungal isolates for Extracellular Enzyme production}

\section{Cellulase Activity}

The fungal isolates were assessed for cellulase activity by streaking on CMC Agar media (containing $\mathrm{K}_{2} \mathrm{HPO}_{4} 1 \mathrm{gm}, \mathrm{MgSO}_{4} 0.5 \mathrm{gm}, \mathrm{NaCl} 0.5 \mathrm{gm}, \mathrm{FeSO}_{4} 0.01 \mathrm{gm}$, $\mathrm{MnSO}_{4} 0.01 \mathrm{gm}, \mathrm{NH}_{4} \mathrm{NO}_{3}-0.03 \mathrm{gm}, \mathrm{CMC} 10 \mathrm{gm}$, Agar-20 gm, distilled water 1 liter) and incubated for 5 days. After fungal growth appearance, the plates were flooded with $0.1 \%$ Congo red solution for 15 mins with gentle shaking and then de-stained with $1 \mathrm{M} \mathrm{NaCl}$ solution for 15 minutes. Appearance of clear zones around fungal colony indicates cellulase activity.

\section{Amylase Activity}

The fungal isolates were assessed for amylase activity by inoculating on Starch Agar media (Beef Extract 3 gm, Soluble Starch 10 gm, Agar 20 gm, distilled water 1 liter) and incubated for $24-48 \mathrm{~h}$. After incubation, the plates were flooded with $1 \%$ 
Gram's iodine solution and observed for the appearance of a clear zone of hydrolysis around the fungal growth.

\section{Screening of endophytic bacteria and fungi for production of antimicrobials}

The endophytic bacterial and fungal isolates from Andrographis paniculata were cultured in $5 \mathrm{ml}$ Nutrient broth and Sabouraud Dextrose broth medium respectively at $32^{\circ} \mathrm{C}$ for 5 days (allowing them to reach stationary growth phase) in a rotary shaker (150 rpm), followed by centrifugation at $8000 \mathrm{rpm}$ for 8 mins. The culture filtrate was used for the screening of antimicrobial activity by agar-diffusion technique on Luria-Bertani agar media that was previously seeded with test pathogens - E. coli, Staphylococcus sp. and Vibrio sp. Sterile broth was set as control. Formation of any inhibition zone was recorded.

\section{RESULTS AND DISCUSSION}

From the surface sterilized Andrographis paniculata, a total of 100 endophyte cfu were observed, of which the highest endophytic consortia were isolated from leaf tissue $(47 \mathrm{cfu})$, followed by the root $(33 \mathrm{cfu})$ and stem tissue $(20 \mathrm{cfu})$. This signified a diverse number of residing endophytes in A. paniculata leaves. Out of 100 endophytic cfu, morphologically distinct 9 bacterial and 6 fungal isolates were considered for further evaluation of their potential roles in the host plant physiological processes (Table 1).

Table 1. Endophytes isolated from Andrographis paniculata

\begin{tabular}{lcccccc}
\hline $\begin{array}{l}\text { Plant } \\
\text { specimen }\end{array}$ & $\begin{array}{c}\text { Endophyte } \\
\text { Type }\end{array}$ & Leaf & Stem & Root & Total & $\begin{array}{c}\text { Microscopic } \\
\text { Characterization }\end{array}$ \\
\hline $\begin{array}{l}\text { Andrographis } \\
\text { paniculata }\end{array}$ & Bacterial & 3 & 3 & 3 & 9 & $\begin{array}{c}\text { Gram (+) rods, few are } \\
\text { gram (-) }\end{array}$ \\
& Fungal & 3 & 2 & 1 & 6 & $\begin{array}{c}\text { Fungal hyphae } \\
\text { identified to be } \\
\text { Alternaria sp. }\end{array}$ \\
\hline
\end{tabular}

The bacterial endophytic isolates were microscopically characterized as gram positive rods, which are consistent with those found in the Cassia tora L. (Kumar et al., 2015) and the fungal endophytic isolate was identified to be Alternaria sp. Also, Aspergillus sp. is identified as endophytes in Andrographis paniculata (Elfita et al., 2015).

In the current study, efforts were made to observe the PGP properties of bacterial endophytes of Andrographis paniculata i.e., IAA production, $\mathrm{N}_{2}$ fixation and phosphate solubilization (Table 2). 
Table 2. Plant Growth Promoting (PGP) Traits of Endophytic Bacterial Isolates of A. paniculata

\begin{tabular}{|c|c|c|c|c|c|}
\hline \multirow{2}{*}{\multicolumn{2}{|c|}{$\begin{array}{l}\text { Endophyte } \\
\text { isolate }\end{array}$}} & \multicolumn{2}{|c|}{ IAA Production } & \multirow[b]{2}{*}{$\begin{array}{c}\text { Phosphate } \\
\text { Solubilization }\end{array}$} & \multirow[b]{2}{*}{$\mathrm{N}_{2}$ fixation } \\
\hline & & Ability & $\begin{array}{l}\text { Concentration } \\
(\mu \mathrm{g} / \mathrm{ml})\end{array}$ & & \\
\hline 1) & APL1-B & - & - & - & - \\
\hline 2) & APL2-B & + & 2 & - & - \\
\hline 3) & APL3-B & + & 12 & - & + \\
\hline 4) & APS1-B & - & - & - & - \\
\hline 5) & APS2-B & + & 31 & + & - \\
\hline 6) & APS3-B & - & - & - & - \\
\hline 7) & APR1-B & + & 15 & - & - \\
\hline 8) & APR2-B & + & 3 & - & - \\
\hline 9) & APR3-B & + & 45 & - & - \\
\hline
\end{tabular}

Out of 9 isolates, 6 were found to produce IAA, the main auxin in higher plants. The root isolate, APR3-B was shown to produce maximum IAA $(45 \mu \mathrm{g} / \mathrm{ml})$, followed by the stem isolate, APS2-B $(31 \mu \mathrm{g} / \mathrm{ml})$ after 10 days incubation with $0.5 \%$ Ltryptophan. This signifies their additive roles in promoting plant root and shoot growth, water and mineral uptake etc. (Liu et al., 2010). No IAA detected in isolates in absence of L-tryptophan suggests that the endophytes synthesize IAA in Ltryptophan dependent indole-3 pyruvic acid (IPA) pathway (Lee et al., 2004). This observation may be interpreted as the endophytes may be deficient of the tryptophan biosynthetic pathway and relies upon the host plant for the amino acid L-tryptophan, the extra amount is converted to IAA by the endophyte for efficient plant growth promotion. This signifies a mutually beneficial plant-microbe interaction. Phosphate solubilization by the endophyte, Achromobacter xylosoxidans is well documented in wheat (Jha and Kumar, 2009). In our study, 1 stem isolate, APS2-B was shown to solubilize P on Pikovskaya medium, as indicated by a clear halo around the colony is another PGP trait observed in the endophytic isolates. Inorganic P in chemical fertilizers gets immobilized in the soil and is unavailable to the plants. However, $\mathrm{P}$ solubilization by rhizospheric microorganisms is well reported (He et al., 2010). The endophytes are also found to be capable of solubilizing the soil $\mathrm{P}$ reserve via production of organic acids and extracellular polysaccharides and releasing them into soil (Goldstein et al., 1995). This makes them ideal candidates for the utilization of soil $\mathrm{P}$ reserve by the plants thus enhancing the crop yields. The highest $\mathrm{P}$ solubilizing endophytes reported seems to be Streptomyces sp. (Hamdali et al., 2008), Bacillus sp., Pseudomonas putida etc (Rajkumar et al., 2006). This solubilized $\mathrm{P}$ is further utilized in secondary metabolite biosynthesis like andrographolide in Andrographis 
paniculata (Vickery and Vickery, 1986). In addition to this, 1 leaf isolate, APL3-B was found to be capable of fixing atmospheric $\mathrm{N}_{2}$ in glucose $\mathrm{N}_{2}$ free minimal media, as indicated by prussian blue coloration. This is another PGP trait conferred by the endophytes towars plant growth and development processes. Till date, rhizospheric microorganisms are well known for their capability of atmospheric $\mathrm{N}_{2}$ fixation (Igiehon et al., 2018), the sole natural source of $\mathrm{N}_{2}$, which is an important macronutrient of plants. The endophytes also fix atmospheric $\mathrm{N}_{2}$ by nitrogenase activity which is encoded by the nifH gene (Tonooka et al., 2008) making them ideal for the supply of plant $\mathrm{N}_{2}$ source. The capability of isolates, APL3-B and APS2-B with diverse PGP traits make them agriculturally potential endophytes.

Beside PGP traits, preliminary screening of Andrographis paniculata fungal endophytic isolates for enzyme production (cellulase and amylase) was also carried out. Among 6 isolates, all were positive for the production of extracellular enzymes viz. cellulase and amylase (Table 3), which confers their potential role in plant pathogen resistance. Various plant pathogens attack plant tissues which are outcompeted and inhibited by the residing endophytic fungi with aid of different extracellular lytic enzymes like chitinase, protease, cellulase etc. production (Choi et al., 2005) which breaks down the plant pathogen cell wall constituting chitin, modified cellulose, starch as storage material (de Bashan et al., 2005).

Table 3. Enzyme Production Assessment of Fungal Endophytic Isolates of A. paniculata

\begin{tabular}{rrcc}
\hline Endophytic Isolate & Cellulase Activity & Amylase Activity \\
\hline 1) & APL1-F & + & + \\
2) & APL2-F & + & + \\
3) & APL3-F & + & + \\
4) & APS1-F & + & + \\
5) & APS2-F & + & + \\
6) & APR1-F & + & + \\
\hline
\end{tabular}

The bacterial endophytes like Bacillus and Pseudomonas sp. induce chitinase expression which reduces the disease severity of plant pathogen - Xanthomonas axonopodis (Rajendran, 2006). These enzymes producing fungal endophytes can also be used as biotechnological sources for industrially and medically important enzymes (Promputtha et al., 2007).

The antimicrobial potential of Andrographis paniculata endophytic extracts were also evaluated against 3 test pathogens - E.coli, Staphylococcus sp. and Vibrio sp. 
Out of the 9 bacterial isolates, 4 isolates (APL1-B, APS2-B, APS3-B and APR3-B) were found to inhibit the test pathogens; of which the stem isolate, APS3-B significantly showed broad spectrum antimicrobial activity against E.coli, Staphylococcus sp. and Vibrio sp. 4 out of 6 fungal endophytic isolates namely, APL1-F, APS1-F, APS2-F and APR1-F were also inhibiting the test pathogens, and the latter 3 of them were found to significantly inhibit both Staphylococcus sp. and Vibrio sp. (Table 4).

Table 4. Antimicrobial Activity of Endophytes of A. Paniculata

\begin{tabular}{cccc}
\hline Isolates & E. coli & Staphylococcus sp. & Vibrio sp. \\
\hline Bacterial & & Zone of Inhibition (in mm) & \\
\hline APL1-B & 15 & - & - \\
APL2-B & - & - & - \\
APL3-B & - & - & - \\
APS1-B & - & - & - \\
APS2-B & - & 13 & - \\
APS3-B & 16 & 13 & 14 \\
APR1-B & - & - & - \\
APR2-B & - & - & - \\
APR3-B & - & 10 & - \\
Fungal & - & & \\
APL1-F & - & - & 17 \\
APL2-F & - & - & - \\
APL3-F & - & - & 11 \\
APS1-F & - & 10 & 12 \\
APS2-F & - & 11 & 13 \\
APR1-F & - & & \\
\hline
\end{tabular}

E. coli is the leading cause of community acquired urinary tract infection (UTI) among $1 / 3^{\text {rd }}$ of women population (Minardi et al., 2011). The phytochemicals extracted from Andrographis paniculata are capable of inhibiting uropathogenic E. coli strains (Sahare and Shinde, 2014) because they contain various essential oils and bioactive compounds with high sensitivity against E.coli (Gupta and Shukla, 2017). Contrarily, our study showed that A. paniculata leaf and stem endophytes (APL1-B and APS3-B) were strongly combating E.coli growth which can be used as an alternative against antibiotics in UTI treatment because the frequent use of antibiotics can cause vaginal and intestinal dysbiosis. Various species of Staphylococcus are opportunistic pathogens which causes a wide range of infections from mild skin 
lesions (Foster et al., 1996) to severe necrotizing pneumonia, bacteremia, endocarditis etc. (Oliveira, 2018). Studies reported that A. paniculata leaf extracts can effectively inhibit Staphylococcus $s p$. at low MIC by oxidative damage via downregulating superoxide dismutase (Hussain and Mustakim, 2017). Our study showed that most of the A. paniculata endophytic bacterial (APS2-B, APS3-B, APR3-B) and fungal isolates (APS1-F, APS2-F, APR1-F) have inhibitory activity against Staphylococcus sp. which is consistent with results of Arunachalam et al., 2010. Vibrio sp., the etiological agent of cholera, gastroenteritis and fulminant sepsis (Morris, 2003) is reported to be potentially inhibited by A. paniculata extracts. This is due to the presence of andrographolide, which is reported to have antiquorum sensing potential in Vibrio harveyi, thus inhibiting biofilm formation and bacterial virulence (Mary et al., 2017). Our study showed that A. paniculata endophytes, mainly fungal endophyte extracts have maximum inhibitory zones against Vibrio $s p$. Our investigation suggested that apart from A. paniculata phyto-extracts, the endophytes can also be used for medical purposes as they have broad and specific antimicrobial activity. Currently, endophytes are reported to be used in pharmaceutical purposes for the discovery of diverse human therapeutic agents like antibiotics, antimycotics, anti-carcinogenics etc. (Guo et al., 2008).

\section{CONCLUSION}

In conclusion, the endophytes of the medicinal plant-Andrographis paniculata are novel and diverse. They exhibit diverse PGP traits that help in the improvement of growth and development of $A$. paniculata and serve as a bioresource of medically important enzymes, which helps the plants in pathogen resistance. They also exhibit potential antagonistic effects against potential human pathogens causing skin, gastrointestinal, and urinary tract infections. Thus, the endophytes are promising sources of bioactive compounds in agricultural, biotechnological and pharmaceutical fields.

\section{REFERENCES}

Ali, S., Charles, T.C. and Glick, B.R. (2017). Endophytic phytohormones and their role in plant growth promotion. In: Doty, S.L., (Editor) Functional importance of the plant microbiome. Springer, Berlin. Pp. 89-105.

Arunachalam, C. and Gayathri, P. (2010). Studies on bioprospecting of endophytic bacteria from the medicinal plant of Andrographis paniculata for their antimicrobial activity and antibiotic susceptibility. International Journal of Current Pharmaceutical Research, 2(4): 63-8.

Bahl, G.S., Pasricha, N.S. and Ahuja, K.L. (2000). Effect of fertilizer nitrogen and phosphorus on the grain yield, nutrient uptake and oil quality of sunflower. Journal of the Indian Society of Soil Science, 45(2): 292-296.

Bal, H.B., Das, S., Dangar, T.K. and Adhya, T.K. (2013). ACC deaminase and IAA producing growth promoting bacteria from the rhizosphere soil of tropical rice plants. Journal of Basic Microbiology, 53: 972-984. 
Chanway, C.P. (1996). Endophytes: they're not just fungi. Canadian Journal of Botany, 74(3): 321-322.

Chen, C., Bauske, E.M., Musson, G., Rodriguez-Kibana, R. and Kloepper, J.W. (1995). Biological control of Fusarium wilt on cotton by use of endophytic bacteria. Biological Control, 5: 83-91.

Choi, Y.W., Hodgkiss, I.J. and Hyde, K.D. (2005). Enzyme production by endophytes of Brucea javanica. Journal of Agricultural Technology, 1: 55-66.

Dastogeer, K.M.G., Li, H., Sivasithamparam, K., Jones, M.G.K. and Wylie, S.J. (2018). Host specificity of endophytic mycobiota of wild nicotiana plants from arid regions of northern Australia. Microbial Ecology, 75(1): 74-87.

de-Bashan, L.E., Antoun, H. and Bashan, Y. (2005). Cultivation factors and population size control uptake of nitrogen by the microalgae Chlorella vulgaris when interacting with the microalgae growth-promoting bacterium Azospirillum brasilense. FEMS Microbiology Ecology, 54: 197-203.

Dubay, V.S., Bhalla, R. and Luthra, R. (2003). Review: An overview of the non-mevalonate pathway for terpenoid biosynthesis in plant. Journal of Bioscience, 28(5): 637-646.

Elfita, E., Muharni, M. and Munawar, M. (2015). Endophytic fungi isolated from Sambiloto (Andrographis paniculata Nees) as a source of fungal lipid production. Journal of Chemical and Pharmaceutical Research, 7(9S): 66-69.

Farnsworth, N.R. (1990). The role of ethnopharmacology in drug development. In: Chadwick, D.J., Marsh, J. (Editors), Bioactive Compounds from Plants. Ciba Foundation Symposium 154, John Wiley and Sons held at Chichester. Pp. 2-21.

Freeman, E.M. (1904). The seed fungus of Lolium temulentum L. the darnel. Philosophical Transactions of the Royal Society of London [Biology], 196: 1-27.

Goldstein, A.H. (1995). Recent progress in understanding the molecular genetics and biochemistry of calcium phosphate solubilization by gram negative bacteria. Biological Agriculture and Horticulture, 12: 185-93.

Goldstein, A.H. (1986). Bacterial solubilization of mineral phosphates: Historical perspective and future prospects. American Journal of Alternative Agriculture, 1: 51-57.

Gordon, S.A. and Weber, R.P. (1951). Colorimetric estimation of indole acetic acid. Plant Physiology, 26: 192-195.

Gunatilaka, A.A.L. (2006). Natural products from plant associated microorganisms: distribution, structural diversity, bioactivity, and implications of their occurrence. Journal of Natural Products, 69(3): 509-526.

Guo, B., Wang, Y., Sun, X. and Tang, K. (2008). Bioactive natural products from endophytes: a review. Applied Biochemistry and Microbiology, 44(2): 136-142.

Guo, L., Yu, H., Zhang, L., Li, L., Zheng, C., Li, W., Sun, P. and Qin, L. (2010). Recent developments and future prospects of antimicrobial metabolites produced by endophytes. Microbiological Research, 165(6): 437-449.

Gupta, V. and Shukla, A.K. (2017). Sensitivity of uropathogenic bacteria against some bioactive compounds of Kalmegha (Andrographis paniculata) and Chirayta (Swertia chirata). International Journal of Science and Research, 6(11): 1380-1384. 
Gusmaini, Aziz, S.A., Munif, A., Sopandie, D. and Bermawie, N. (2013). Isolation and selection of endophytic bacteria consortia from medicinal plant (Andrographis paniculata) as plant growth promoting agents. Journal of Agronomy, 12(3): 113-121.

Hallmann, J., Hallmann, A.Q., Mahaffee, W.F. and Kloepper, J.W. (1997). Bacterial endophytes in agricultural crops. Canadian Journal of Microbiology, 43: 895-914.

Hamdali, H., Bouizgarne, B., Hafidi, M., Lebrihi, A., Virolle, M.J. and Ouhdouch, Y. (2008). Screening for rock phosphate-solubilizing Actinomycetes from Moroccan phosphate mines. Applied Soil Ecology, 38: 12-19.

He, L.Y., Zhang, Y.F., Ma, H.Y., Su, L.N., Chen, Z.J., Wang, Q.Y., Meng, Q. and Fang, S.X. (2010). Characterization of copper resistant bacteria and assessment of bacterial communities in rhizosphere soils of copper-tolerant plants. Applied Soil Ecology, 44: $49-55$.

He, Z.L. and Zhu, J. (1998). Microbial utilization and transformation of phosphate adsorbed by variable charge minerals. Soil Biology and Biochemistry, 30: 917-923.

Hussain, M. I., Asghar, H. N., Akhtar, M. J. and Arshad, M. (2013). Impact of phosphate solubilizing bacteria on growth and yield of maize. Soil and Environment, 32(1): 7178.

Hussain, R.M., Razak, Z.N.R.A., Saad, W.M.M. and Mustakim, M. (2017). Mechanism of antagonistic effects of Andrographis paniculata methanolic extract against Staphylococcus aureus. Asian Pacific Journal of Tropical Medicine, 10(7): 685-695.

Igiehon, N.O. and Babalola, O.O. (2018). Rhizosphere microbiome modulators: Contributions of nitrogen fixing bacteria towards sustainable agriculture. International Journal of Environmental Research and Public Health, 15: 574.

James, E.K. and Olivares, F.L. (1998). Infection and colonization of sugarcane and other gramineous plants by endophytic diazotrophs. Critical Reviews in Plant Sciences, 17: 77-119.

Jha, P. and Kumar, A. (2009). Characterization of novel plant growth promoting endophytic bacterium Achromobacter xylosoxidans from wheat plant. Microbial Ecology, 58: 179188.

Kado, C.I. (1992). Plant pathogenic bacteria. In: The Prokaryotes, Balows, A., Truper, H.G., Dworkin, M., Harder, W. (Editors). Springer Science, New York. Pp. 659-674.

Lee, S., Flores-Encarnacion, M., Contreras-Zentella, M., Garcia-Flores, L., Escamilla, J. E., and Kennedy, C. (2004). Indole-3-acetic acid biosynthesis is deficient in Gluconacetobacter diazotrophicus strains with mutations in cytochrome C biogenesis genes. Journal of Bacteriology, 186(16): 5384-5391.

Liu, X., Jia, J., Atkinson, S., Camara, M., Gao, K., Li, H. and Cao, J. (2010). Biocontrol potential of an endophytic Serratia sp. G3 and its mode of action. World Journal of Microbiology and Biotechnology, 26: 1465-1471.

Lu, L., He, C., Jin, Y., Zhang, X. and Wei, J. (2013). Effects of application of phosphorus and potassium fertilizers at different growth stages on the growth and bioactive compounds of Salvia miltiorrhiza Bunge. Australian Journal of Crop Science, 7(10): 1533-1543. 
Mary, R. and Narasimhan, B. (2017). Antiquorum Sensing Potential of Andrographolide from Andrographis paniculata in Vibrio harveyi. Research Journal of Pharmacy and Technology, 10: 449.

Minardi, D., d' Anzeo, G., Cantoro, D., Conti, A. and Muzzonigro, G. (2011). Urinary tract infections in women: etiology and treatment options. International Journal of General Medicine, 4: 333-43.

Morris, J.G. (2003). Cholera and other types of vibriosis: a story of human 643 pandemics and oysters on the half shell. Clinical Infectious Diseases, 37: 272-280.

Muangthong, A., Youpensuk, S. and Rerkasem, B. (2015). Isolation and characterization of endophytic nitrogen fixing bacteria in sugarcane. Tropical Life Sciences Research, 26: 41-51.

Mukhopadhyay, M. and Adhikari, M. (2020). Endophytes of Catharanthus roseus: A potential source of plant growth promoters and antimicrobial compounds. Journal of Advanced Scientific Research, 11(2): 209-212.

Oliveira, D., Borges, A. and Simoes, M. (2018). Staphylococcus aureus toxins and their molecular activity in infectious diseases. Toxins, 10: 252.

Pikovskaya, R.I. (1948). Mobilization of Phosphorus in Soil Connection with the Vital Activity of Some Microbial Species. Microbiology, 17: 362-370.

Promputtha, I., Lumyong, S., Dhanasekaran, V., McKenzie, E.H.C., Hyde, K.D. and Jeewon, R. (2007). A phylogenetic evaluation of whether endophytes become saprotrophs at host senescence. Microbial Ecology, 53: 579-590.

Quispel, A. (1992). A search of signal in endophytic microorganisms. In: Verma, D.P.S. (Editor). Molecular signals in plant - microbe communications, CRS Press, Boca Raton, FL. Pp. 475-491.

Radji, M., Sumiati, A., Rachmayani, R. and Elya, B. (2011). Isolation of fungal endophytes from Garcinia mangostana and their antibacterial activity. African Journal of Biotechnology, 10(1): 103-107.

Rajendran, L., Saravanakumar, D., Raguchander, T. and Samiyappan, R. (2006). Endophytic bacterial induction of defence enzymes against bacterial blight of cotton. Phytopathologia Mediterranea, 45: 203-214.

Rajkumar, M., Nagendran, R., Kui, J.L., Wang, H.L., and Sung, Z.K. (2006). Influence of plant growth promoting bacteria and $\mathrm{Cr}$ (VI) on the growth of Indian mustard. Chemosphere, 62: 741-748.

Rao, C.H.V., Azmi, L. and Gupta, S.S. (2014). Phytochemical and pharmacological review on Andrographis serpyllifolia: Potential herbal cure-all. Mintage journal of Pharmaceutical and Medical Sciences, 3(3): 1-3.

Saber, K., Nahla, L.D. and Chedly, A. (2005). Effect of P on nodule formation and N fixation in beans. Agronomy for Sustainable Development, 25: 389-393.

Sahare, P., Moon, A. and Shinde, G.B. (2014). In vitro Phytochemical analysis combating urinary tract infection with Andrographis paniculata. Journal of Pharmaceutical, Chemical and Biological Sciences, 2(2): 93-103 
Sarker, B.C. and Karmoker, J.L. (2011). Effects of phosphorus lentil deficiency on accumulation of biochemical compounds in (Lens culinaris medik.). Bangladesh Journal of Botany, 40(1): 2327.

Shi, Y.W., Lou, K. and Li, C. (2009). Isolation, quantity distribution and characterization of endophytic microorganisms within sugar beet. African Journal of Biotechnology, 8: 835-840.

Siciliano, S.D., Fortin, N., Mihoc, A., Wisse, G., Labelle, S., Beaumier, D., Ouellette, D., Roy, R., Whyte, L.G., Banks, M.K., Schwab, P., Lee, K. and Greer, C.W. (1998). Selection of specific endophytic bacterial genotypes by plants in response to soil contamination. Applied and Environmental Microbiology, 67: 2469-2475.

Sicuia, B. and Cornea, C.P. (2019). Isolation procedures for endophytes harvesting. Agro Life Scientific Journal, 8(1): 43-52

Strobel, G. and Daisy, B. (2003). Bioprospecting for microbial endophytes and their natural products. Microbiology and Molecular Biology Reviews, 67: 491-502.

Sulandjari, Linayanti, and Wartoyo. (2007). Phosphorus and paclobutrazol, its effect on yield and quality oil of Mentha arvensis L. Proceedings national seminar on Hortikultura. Pp. 556-559.

Sunitha, V.H., Nirmala Devi, D. and Srinivas, C. (2013). Extracellular enzymatic activity of endophytic fungal strains isolated from medicinal plants. World Journal of Agricultural Sciences, 9(1): 1-9.

Taghavi, S., Garafola, C., Monchy, S., Newman, L., Hoffman, A., Weyens, N., Barac, T., Vangronsveld, J. and Vander Lelie, D. (2009). Genome survey and characterization of endophytic bacteria exhibiting a beneficial effect on growth and development of poplar trees. Applied and Environmental Microbiology, 75(3): 748-757.

Terakado-Tonooka, J., Owaki, Y., Yamakawa, H., Tanaka, F., Yoneyama, T. and Fujihara, S. (2008). Expressed nifH genes of endophytic bacteria detected in field-grown sweet potatoes (Ipomoea batatas L.). Microbes and Environments, 23: 89-93.

Ulrich, K., Ulrich, A. and Ewald, D. (2008). Diversity of endophytic bacterial communities in poplar grown under field conditions. FEMS Microbiology Ecology, 63: 169-180.

Uzma, F., Konappa, N.M. and Chowdappa, S. (2016). Diversity and extracellular enzyme activities of fungal endophytes isolated from medicinal plants of Western Ghats, Karnataka. Egyptian Journal of Basic and Applied Sciences, 3(4): 335-342.

Kumar, V., Kumar, A., Pandey, K.D. and Roy, B.K. (2015). Isolation and characterization of bacterial endophytes from the roots of Cassia tora L. Annals of Microbiology, 65(3): 1391-1399.

Vickery, M.L. and Vickery, B. (1986). Secondary Plant Metabolism. The Macmillan Press Ltd. Pp.112-154.

Xu, Y., Marshall, R.L. and Mukkur, T.K.S. (2006). An investigation on the antimicrobial activity of Andrographis paniculata extracts and andrographolide in vitro. Asian Journal of Plant Sciences, 5: 527-530. 
Yaish, M.W., Antony, I. and Glick, B.R. (2015). Isolation and characterization of endophytic plant growth-promoting bacteria from date palm tree (Phoenix dactylifera L.) and their potential role in salinity tolerance. Antonie van Leeuwenhoek, 107: 1519-1532.

Zhang, Z., Jiang, J., Yu, P., Zeng, X., Larrick, J.W. and Wang, Y. (2009). Hypoglycemic and beta cell protective effects of andrographolide analogue for diabetes treatment. Journal of Translational Medicine, 7: 62. 